\title{
Service life extension of state highway 16 bridges - New Zealand's first hybrid corrosion protection application
}

\author{
Christian Christodoulou ${ }^{1}$, Ryan Cobbs $^{1}$, Paul Corbett $^{2}$ and Mike Elliot ${ }^{3}$ \\ ${ }^{1}$ AECOM Ltd, Birmingham, U.K. \\ ${ }^{2}$ Jacobs, Auckland, New Zealand \\ ${ }^{3} \mathrm{CPB}$, Auckland, New Zealand
}

\begin{abstract}
State Highway 16 (SH16) is an existing motorway of significant strategic importance connecting central Auckland to the city's western suburbs and beyond. It carries, on average, some 90,000 vehicles per day, and runs through an environmentally sensitive coastal marine reserve. Two highway bridges, namely Whau River Bridge and Causeway Bridge are currently being refurbished due to extensive chloride contamination as a result of exposure to a tidal marine environment and exhibit surface cracking, spalling and reinforcement corrosion. A hybrid corrosion protection system has been selected as the preferred corrosion management solution to arrest corrosion and to ensure a residual service life of 50 years. The hybrid corrosion protection (HCP) system comprises discrete zinc anodes which were installed on both the reinforced and pre-stressed concrete piles from the Lowest Astronomical Tide (LAT) level, up to the soffit of the crossbeams. The anodes operate in two phases, initially energised using low voltage DC power to arrest ongoing corrosion and thereafter in galvanic mode to provide corrosion prevention for the residual service life. HCP minimised physical works on site, negated the requirement for extensive replacement of chloride contaminated concrete, allowed work to take place accommodating incoming and outgoing tides and offers protection against chloride induced corrosion to the substructures. This is the first HCP system designed and installed in New Zealand, and it is believed to be the first of its kind for pre-stressed concrete in tidal water in the world.
\end{abstract}

\section{Introduction}

State Highway 16 (SH16) is an existing motorway of significant strategic importance connecting central Auckland to the city's western suburbs and beyond. It carries, on average, some 90,000 vehicles per day, and runs through an environmentally sensitive coastal marine reserve.

Approximately $4.8 \mathrm{~km}$ of the motorway, from Great North Road Interchange in the east to the Whau River in the west, has been improved under the NZ Government's SH16 Causeway Upgrade project delivered by the NZ Transport Agency and Causeway Alliance. It comprises the widening of the Great North Road to the Whau River section of SH16 to cater for the Western Ring Route traffic, and also safeguarding it against future coastal erosion and flooding by raising and protecting the motorway (Figure 1).

The strategic objectives of the project were:

- Provide a second route through Auckland in addition to State Highway 1;

- Increase motorway capacity, reducing traffic on local roads;

- Efficient links to and from Auckland Airport, Ports of Auckland and inland freight hubs, and;
- More transport options including bus lanes and walking and cycling

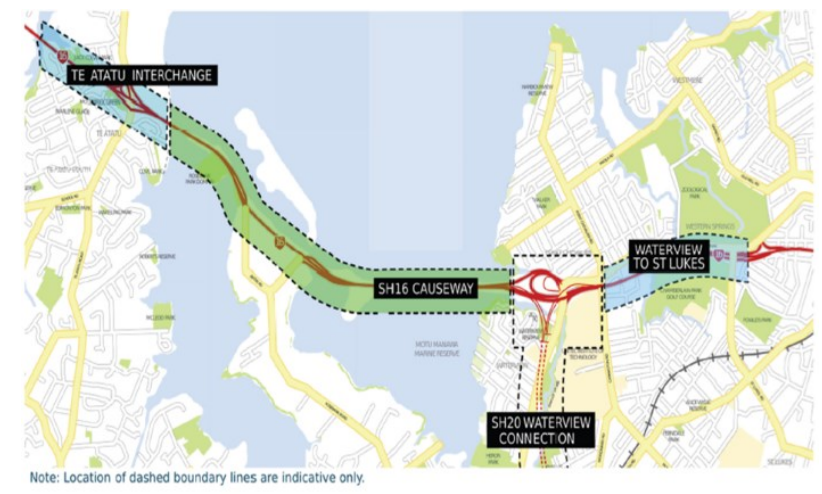

Fig. 1. Western Connection Project, General Arrangement (Corbett \& Watterson, 2016)

One of the key features is the widening of existing bridge structures on this section in order to provide additional capacity for vehicular, pedestrian and cycle traffic. This work also involved protecting the substructure of existing bridges from material deterioration (Corbett \& Watterson, 2016). Retention of the existing bridges as part of the Causeway Upgrade 
project both ensured a sustainable use of existing materials and resources and brought economic benefits. The cost of completely replacing the existing bridges, which had not yet reached the end of their service life, would have been significantly more expensive and replacement would have also caused significant disruption in an environmentally sensitive coastal marine reserve.

\section{Bridges}

There are two existing bridges on SH16, namely Whau River Bridge and Causeway Bridge. Each of these bridges comprises two separate structures: a northern structure carrying the three-lane eastbound SH16 carriageway, and a southern structure carrying both the three-lane westbound SH16 carriageway and the north-western Cycleway.

The original structures to both bridges were built in the 1950s/1960s, with each northern structure initially carrying single lane traffic in two directions prior to duplication by the southern structure. Widening on each structure's outer edge, carried out in the 1990s, provided additional carriageway width (Corbett \& Watterson, 2016).

\subsection{Whau River Bridge}

Whau River Bridge (Figure 2) is a 182m long, eight-span bridge crossing the Whau River, situated at the western end of the project. The superstructure consists of reinforced concrete rectangular deck beams and deck slab cast monolithically onto reinforced concrete supports. The substructure comprises the following different structural arrangement depending on the actual construction date (Corbett \& Watterson, 2016):

- Original 1950s northern structure: a twin-leg portal frame at each support location (pile Type 1A), supported on a pair of $2.4 \mathrm{~m}$ diameter shallow caisson foundations;

- 'duplicate' 1950s southern structure: four 1m diameter bored cast-in-situ piles at each support location (pile Type

- 2A), with in situ reinforced concrete jackets retrofitted to piles within the tidal zone;

- 1990s widening (northern and southern structures): one $1.5 \mathrm{~m}$ diameter bored cast-in-situ pile at each support location (pile Types 1B and 2B).

\subsection{Causeway Bridge}

Causeway Bridge is a $75 \mathrm{~m}$ long, five-span bridge that crosses the Oakley inlet waterway, located at one end of a causeway section at the eastern end of the project (Figure 3). The substructure comprises the following different structural arrangements depending on construction date (Corbett \& Watterson, 2016):

- Original 1950s northern structure: rectangular reinforced concrete deck beams and transverse headstocks supported on $450 \mathrm{~mm}$ square precast reinforced concrete driven piles (type 1A), with piles raked longitudinally at the eastern abutment;
- 'duplicate' 1960s southern structure: precast pretensioned concrete I-beams and reinforced concrete transverse headstocks supported on $400 \mathrm{~mm}$ square precast pre-tensioned concrete driven piles (type 2A) at the eastern abutment and intermediate piers and on steel H-piles at the western abutment, with abutment piles generally raked longitudinally;

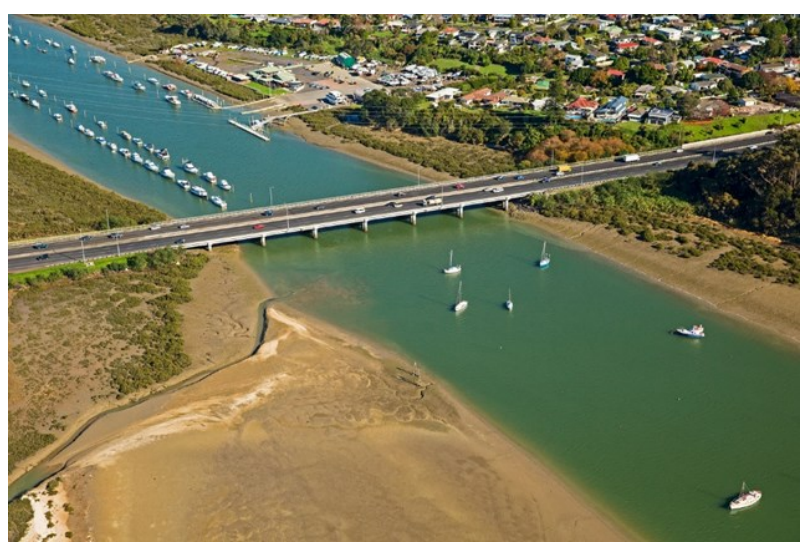

Fig. 2. Aerial view of the existing Whau River Bridge, looking south-west (Corbett \& Watterson, 2016)

- 1990s widening (northern and southern structure): precast pre-tensioned concrete U-beams and reinforced concrete transverse headstocks supported on $450 \mathrm{~mm}$ octagonal precast pre-tensioned concrete driven piles (type 1B and 2B), with abutment piles raked longitudinally.

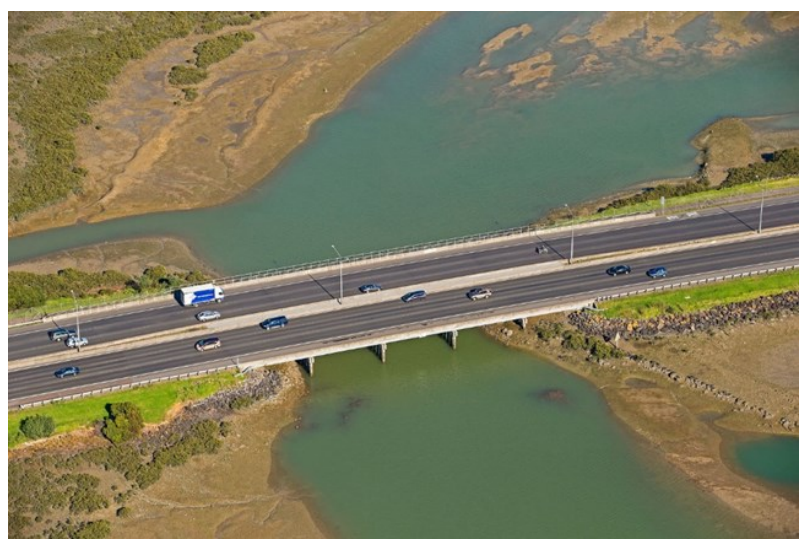

Fig. 3. Aerial view of the existing Causeway Bridge, looking south-west (Corbett \& Watterson, 2016)

\subsection{Durability Assessment}

Prior to the start of any works, both structures underwent a full durability assessment and special investigations in order to establish their current condition and through the use of mathematical models also predict their condition in 50 years' time. The contractual requirement was to achieve a 50 year service life extension and with a 25 year maintenance plan linked to $20 \%$ of bridge capital replacement (circa $\$ 8 \mathrm{M}$ ).

The following test methods were used in the special investigations of the structures:

- Visual examination; 
- Chloride content sampling at varying depths;

- Depth of carbonation;

- Compressive strength;

- Cement content/type;

- Reinforcement continuity;

- Resistivity of the concrete;

The piles exhibited various level of deterioration ranging from cracking, to delamination, spalling and section loss. A typical example of their condition is shown in Figure 4 below.

A recent study by Christodoulou et al. [13, 14] investigated the long-term benefits of the early conductive coating anode systems with a view to improving the design approach, reduce maintenance requirements and ultimately reduce initial capital costs.
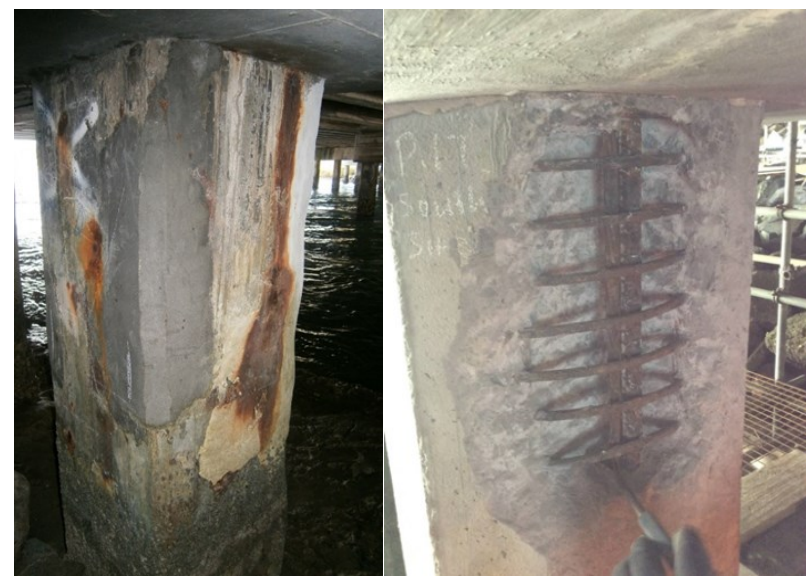

Fig. 4. Typical condition of substructure, showing corrosion staining, spalling, failure of previous concrete repairs and section loss.
Cover to the reinforcement varied significantly between $40 \mathrm{~mm}$ and $80 \mathrm{~mm}$ in the piles, depending on their age of construction with newer piles achieving higher cover to the reinforcement. In a similar manner, cement content ranged from $12.8-17 \%$ by weight and the average was approximately $14.2 \%$ (Christodoulou et al. 2016).

Chloride content also varied significantly depending on the pile type and its age of construction. Sampling was undertaken by taking cores at specified depths from the surface. The samples were then grinded into fine powder and the concentration of chloride was determined and recorded as a percentage of total weight of concrete. An extract from a typical chloride content and cover summary reporting is shown in Table 1 below.

The maximum and minimum concentrations recorded for each pile at the depth of the reinforcement are presented below, in Table 2. Overall, there were over 55 samples taken across the bridge.

Overall, the chloride content at the level of the reinforcement was higher than the general industry accepted threshold of $0.06 \%$ by weight of concrete for plain steel and $0.03 \%$ by weight of concrete for prestressed steel (Bamford \& Price, 1996), (Concrete Society, 2004), (Angst et al. 2009).

Colorimetric testing was used to determine the depth of carbonation within each sample. Overall, carbonation was not found to be extensive nor at depth. In the majority of cases it was in the region of 1 to $3 \mathrm{~mm}$, with only one occasional measurement as high as $23 \mathrm{~mm}$. Nevertheless, even this isolated reading was well below the depth of the reinforcement and as such carbonation is not considered the cause of structural deterioration.

Further to the above, mathematical modelling of

Table 1. Typical concrete cover and chloride concentration reporting summary. RC - reinforced concrete PS -prestressed concrete $\mathrm{T}$ - tidal zone $\mathrm{NR}$ - no records Orange highlighted cells indicate chloride concentration above element specific

\begin{tabular}{|c|c|c|c|c|c|c|c|c|c|c|c|c|c|c|c|c|c|c|}
\hline & \multirow{3}{*}{$\begin{array}{l}\text { Core \& } \\
\text { Photo } \\
\text { Record } \\
\text { Ref No. }\end{array}$} & \multirow{3}{*}{ Location } & \multirow{3}{*}{ 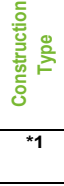 } & \multirow{3}{*}{ 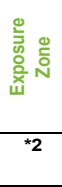 } & \multirow{3}{*}{ 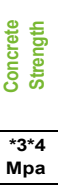 } & \multirow{3}{*}{ 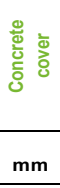 } & \multirow{3}{*}{ 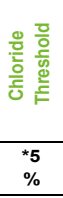 } & \multicolumn{11}{|c|}{ Percentage of Chloride within the Concrete Specimen by weight (\%) } \\
\hline & & & & & & & & A & B & C & D & $\mathrm{E}$ & $\mathbf{F}$ & G & $\mathrm{H}$ & I & $J$ & L \\
\hline & & & & & & & & 4 & 8.4 & 11.5 & 17.5 & & 41 & 47 & & $63+$ & & \\
\hline 2 & $\begin{array}{l}\text { RP07/0.00/ } \\
\mathrm{B} 1 \mathrm{~A} / \mathrm{PE} / 02\end{array}$ & $\begin{array}{c}\text { B1A Pier } \\
\text { E02 }\end{array}$ & RC & $\begin{array}{lll}\mathbf{T} & \\
\end{array}$ & NR & 50 & $\begin{array}{l}\mathbf{( 0 . 2 )} \\
0.05\end{array}$ & 1.245 & 0.864 & - & 0.770 & $\begin{array}{l}\mathbf{0 . 3 3 7} \\
(25.5)\end{array}$ & 0.235 & -- & $\begin{array}{l}\mathbf{0 . 0 8 3} \\
(52.4)\end{array}$ & $\begin{array}{l}\mathbf{0 . 0 3 9} \\
(63.0)\end{array}$ & $\begin{array}{l}\mathbf{0 . 0 4 6} \\
(81.0)\end{array}$ & $\begin{array}{r}\mathbf{0 . 0 1 8} \\
(135.0)\end{array}$ \\
\hline 4 & $\begin{array}{l}\mathrm{RP} 07 / 0.00 / \\
\mathrm{B} 1 \mathrm{~A} / \mathrm{PE} / 04\end{array}$ & $\begin{array}{c}\text { B1A Pier } \\
\text { E04 }\end{array}$ & RC & $\begin{array}{lll}T & \\
\end{array}$ & NR & 50 & $\begin{array}{l}\mathbf{( 0 . 2 )} \\
0.05\end{array}$ & 0.725 & 0.492 & - & 0.419 & $\begin{array}{l}0.362 \\
(27.5)\end{array}$ & 0.119 & - & $\begin{array}{l}\mathbf{0 . 0 6 9} \\
(51.2)\end{array}$ & $\begin{array}{l}\mathbf{0 . 0 1 4} \\
(68.5)\end{array}$ & $\begin{array}{l}\mathbf{0 . 0 1 4} \\
(72.5)\end{array}$ & $\begin{array}{l}\mathbf{0 . 0 1 1} \\
(128.0)\end{array}$ \\
\hline 6 & $\begin{array}{l}\text { RP07/0.00/ } \\
\mathrm{B} 1 \mathrm{~B} / \mathrm{PE} / 02\end{array}$ & $\begin{array}{c}\text { B1B Pier } \\
\text { E09 }\end{array}$ & PS & $\begin{array}{ll}T \\
\text { T }\end{array}$ & 30 & 50 & $\begin{array}{l}\mathbf{( 0 . 1 )} \\
0.03 \\
\end{array}$ & 0.892 & 0.538 & $\begin{array}{l}\mathbf{0 . 4 8 7} \\
(10.0)\end{array}$ & 0.400 & $\begin{array}{c}0.27 \\
(28.0) \\
\end{array}$ & 0.217 & -- & $\begin{array}{l}\mathbf{0 . 1 9 5} \\
(47.5)\end{array}$ & - & - & - \\
\hline
\end{tabular}

Table 2. Minimum and maximum chloride ion concentrations for each bridge pile at the depth of reinforcement; results reported by percentage weight of concrete.

\begin{tabular}{|l|c|c|c|c|}
\hline \multirow{2}{*}{ Pile Type } & \multicolumn{2}{|c|}{ Whau Bridge } & \multicolumn{2}{c|}{ Causeway Bridge } \\
\cline { 2 - 5 } & Min & Max & Min & Max \\
\hline Type 1A & 0.04 & 0.32 & 0.12 & 0.3 \\
\hline Type 2A & 0.06 & 0.1 & 0.03 & 0.13 \\
\hline Type 1B/2B & 0.02 & 0.22 & 0.02 & 0.25 \\
\hline
\end{tabular}


chloride concentration and predictive modelling was undertaken in accordance with Fick's 2nd Law as specified in ASTM C1556 - 04 and also NZTA Report 337 - Deterioration of Prestressed Concrete Bridge Beams.

The calculations give the time at which the chloride content of the concrete at the depth of interest will reach the threshold for corrosion to commence (also known as the "Time to Corrosion Initiation"). Calculations only predict when conditions in the concrete may be such that corrosion may begin; not when it will begin and not when physical damage such cracking and spalling occurs. A typical example of this analysis is shown in Figure 5 below.

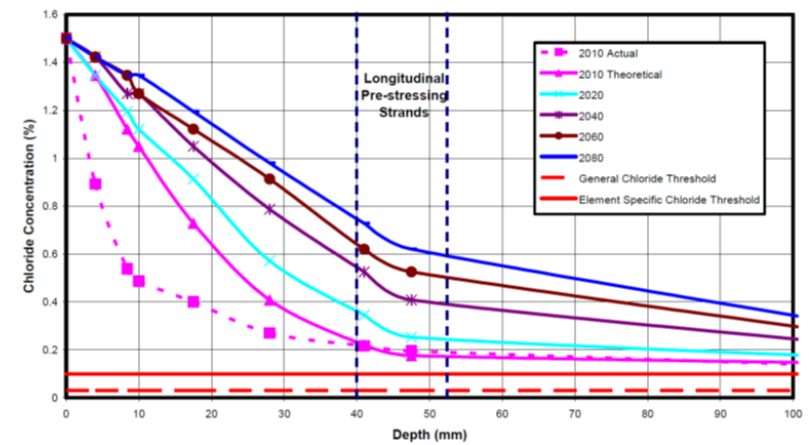

Fig. 5. Typical output of mathematical modelling for chloride concentration.

Overall, the results of the special investigation indicated that the observed deterioration was chloride induced. The chloride concentration was already at a significant level above the commonly accepted level by the industry which warrants intervention before deterioration makes the structures beyond repair and serviceability.

\section{Hybrid corrosion protection}

Hybrid corrosion protection combines the advantages of both Impressed Current Cathodic Protection (ICCP) and galvanic anode technology into one system. It comprises a discrete zinc anode system which is installed into predrilled cavities within reinforced concrete (Figure 6). Compared to ICCP and galvanic protection, hybrid is a relatively new development in electrochemical protection treatments.

The hybrid anodes are manufactured using $18 \mathrm{~mm}$ zinc cylinders, ranging from 42 to $220 \mathrm{~mm}$ long, with an integrated titanium connector wire. A coating is applied to the surface of the anode in order to keep the anode active throughout its design life.

Initially, the system is connected to a temporary, constant $9 \mathrm{~V} \mathrm{DC}$ power supply, typically for a period of at least 1 week, depending on the type of reinforcement (e.g. mild steel or prestressed), to deliver a charge to the reinforcing steel. This initial impressed treatment phase re-passivates the reinforcement by means of generating a reservoir of alkali at the steel - concrete interface
(Christodoulou and Kilgour 2013, Glass et al. 2012, Holmes et al. 2011).

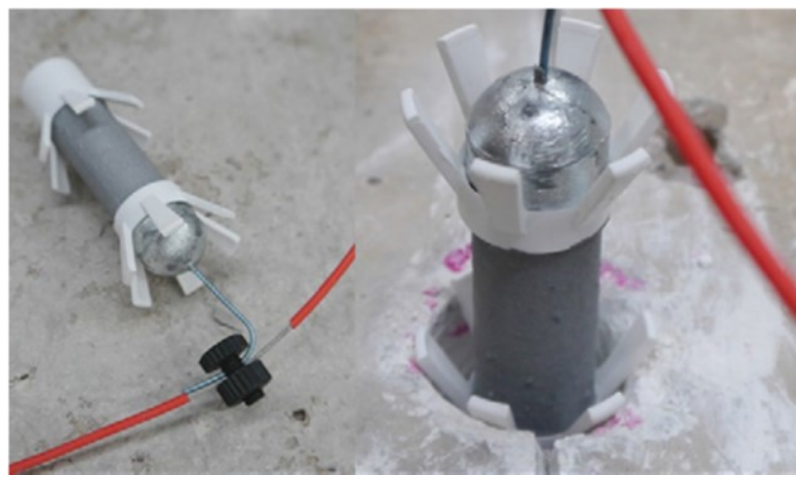

Fig. 6. Typical view of hybrid anodes and the integrated connection to the titanium feeder.

During this initial impressed current phase a charge will be delivered to the reinforcement which is responsible for restoring passivity. The exact amount of charge varies depending on concrete mix design, bulk resistivity, chloride contamination and the steel-concrete interfacial condition. However, studies have shown that generally a charge in the order of $50 \mathrm{kC} / \mathrm{m}^{2}$ of steel surface area will be sufficient (Dodds et al. 2016, Glass et al. 2008, Holmes et al. 2013, Polder et al. 2009).

The hybrid anode is then disconnected from the temporary DC power supply and connected directly to the steel reinforcement, creating a galvanic cell, similar to a battery. This latter treatment phase continues for the remainder of the anodes' working life and provides a relatively low current to the steel reinforcement to maintain steel passivity.

\section{Design approach}

Each pile was zoned in accordance with its relevant environmental exposure, creating 3 distinct zones:

- Tidal zone; from Mean Low Water Springs to $0.5 \mathrm{~m}$ above Mean High Water Springs;

- Splash zone; from $0.5 \mathrm{~m}$ above Mean High Water Springs to $1.0 \mathrm{~m}$ above Highest Astronomical Tide;

- Atmospheric zone; from $1.0 \mathrm{~m}$ above Highest Astronomical Tide to the soffit of the beams;

The design parameters used were the following:

- Initial charge of $50 \mathrm{kC} / \mathrm{m}^{2}$ to the reinforcement;

- Provision for an additional charge of $50 \mathrm{kC} / \mathrm{m}^{2}$ to the reinforcement;

- Anode utilisation factor of 0.9;

- System efficiency of 0.9 ;

- Galvanic design current density of $2 \mathrm{~mA} / \mathrm{m}^{2}$;

- Design life of 50 years;

Hybrid anodes $18 \mathrm{~mm}$ in diameter and of varying length (165 to $220 \mathrm{~mm}$ ) were installed in pre-drilled cavities. The pre-drilled cavities were filled with a proprietary low strength mortar to fully cover the anodes and provide separation from the repair concrete (Figure 7). The hybrid anodes included an integral titanium wire 
to facilitate the delivery of an initial temporary impressed current and were connected in series for each zone.

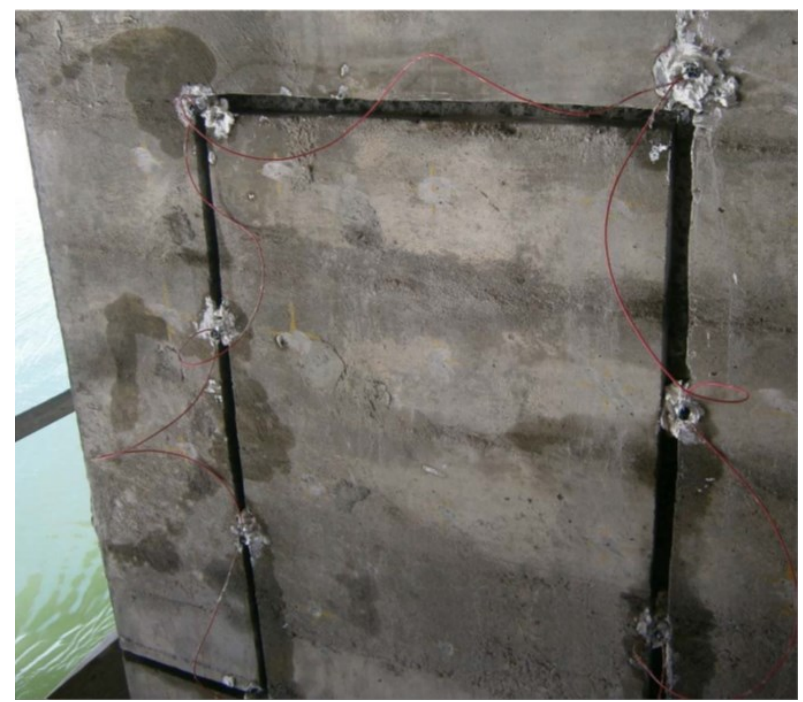

Fig. 7. Typical installation of hybrid anodes.

Wiring for each zone of anodes was terminated in a junction box which also facilitated a connection to the steel reinforcement. This provided a convenient location to connect them to the temporary power supply for delivering the initial current treatment and later connecting them together in a galvanic cell.

Monitoring of the performance of the hybrid corrosion protection system is undertaken by means of a data logging system housed in IP65 cabinets at the abutments of each bridge. Data transfer is achieved by directly wiring the connections from the junction box to the monitoring boxes using XLPE/PVC $(\mathrm{Cu})$ cabling. All cables are secured on cable trays along the face of the headstocks, and then run onto cable trunking along the length of the bridge to terminate into the monitoring boxes.

The performance monitoring system has been designed to capture the following data:
a) Steel potentials;
b) Anode current output;
c) Corrosion current density by means of
polarisation resistance;

Corrosion rate is commonly measured using the polarisation resistance method and it is usually expressed as a current density, a rate of weight loss or a rate of section loss (Polder, et al., 1993), (Andrade \& Alonso, 2004). A corrosion current density of $1 \mathrm{~mA} / \mathrm{m}^{2}$ is approximately equal to a steel section loss of $1 \mu \mathrm{m} /$ year. In general, corrosion current densities higher than 2 $\mathrm{mA} / \mathrm{m}^{2}$ are considered to be significant (Concrete Society, 2004), (Christodoulou, et al., 2010), (British Standard Institution, 2016), (Christodoulou, et al., 2012).

\section{Results}

Figure 8 below demonstrates the typical charge density and current applied to each zone during the initial energisation phase to deliver the required $50 \mathrm{kC} / \mathrm{m}^{2}$. Such data were collected for each and every zone on each of the bridge piles which were monitored continuously during their initial energisation phase.

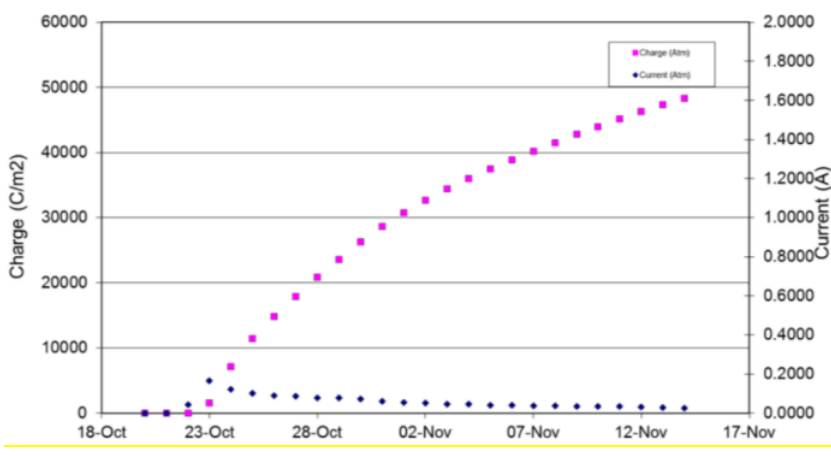

Fig. 8. Typical charge density and current applied to a zone.

Following completion of the initial energisation phase, each zone undergoes a performance assessment in accordance to ISO 12696 (BSI 2016). Figure 9 below demonstrates the typical depolarisation of an atmospheric zone. As it can be observed, the zone achieved a depolarisation of over $100 \mathrm{mV}$ and as such the steel in this zone is considered to be cathodically protected.

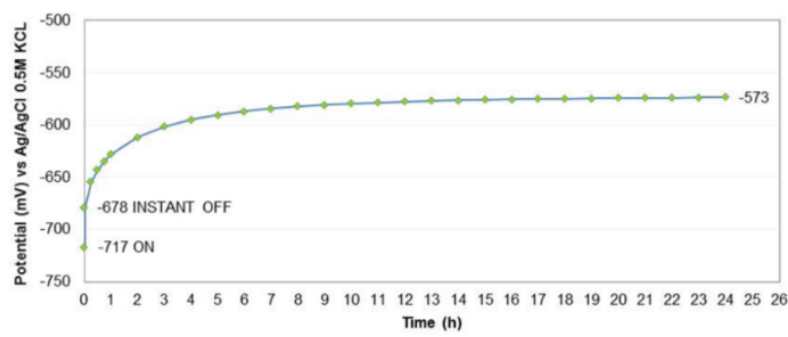

Fig. 9. Typical depolarisation results (over a period of 24 hours) for an atmospheric zone $(\Delta \mathrm{E}=105 \mathrm{mV})$

The best depolarisation results were recoded for one of the splash zones which exhibited a total depolarisation of $240 \mathrm{mV}$ over a period of just 24 hours (Figure 10). This demonstrates further that the steel has been passivated following the application of the initial energisation phase and the hybrid anodes have also achieved cathodic protection.

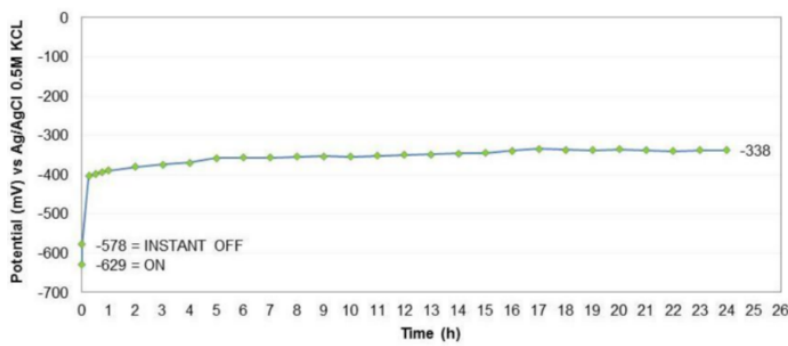

Fig. 10. Typical depolarisation results (over 24 hours) for a splash zone $(\Delta \mathrm{E}=240 \mathrm{mV})$

Assessing the performance of a corrosion protection system in tidal waters is more complex due to the effects of continuously changing environmental conditions and the effect of oxygen depletion in mixed steel potentials. It 
was for this exact reason that the reference steel potentials prior to the installation of the hybrid anodes were also recorded.

Figure 11 below demonstrates the typical data from a reference electrode installed in the tidal zone over a period of 24 hours, with 5 second sampling. It can be observed that the steel undergoes a cycle of reducing potentials for approximately 3 hours, during high tide. It can be observed that this is a sudden event with a nearly vertical slope. Thereafter, the steel depolarises for a period of approximately 9 hours following the outgoing tide, before the cycle is repeated.

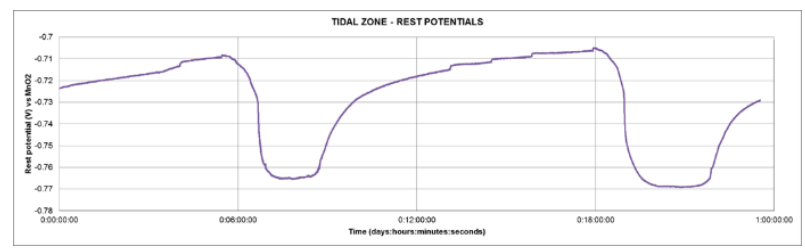

Fig. 11. Typical rest steel potentials in a tidal zone.

From the above graph, it can be observed that the typical potential difference between low and high is approximately $55 \mathrm{mV}$. Similar behaviour was observed from all tidal zones, albeit the potential difference between low and high tide ranged between $40 \mathrm{mV}$ and 65 $\mathrm{mV}$, depending on the pile type and the position of the reference electrode.

From all of the above, it was reasonably expected that tidal zones will not achieve a depolarisation of $100 \mathrm{mV}$ in 24 hours. In fact, it was not expected that such a depolarisation would be achieved at all even over longer periods of time due to the natural limitations on mixed potentials imposed by the tides and the associated oxygen depletion. Such a typical behaviour of a tidal zone is demonstrated in Figure 12 below.

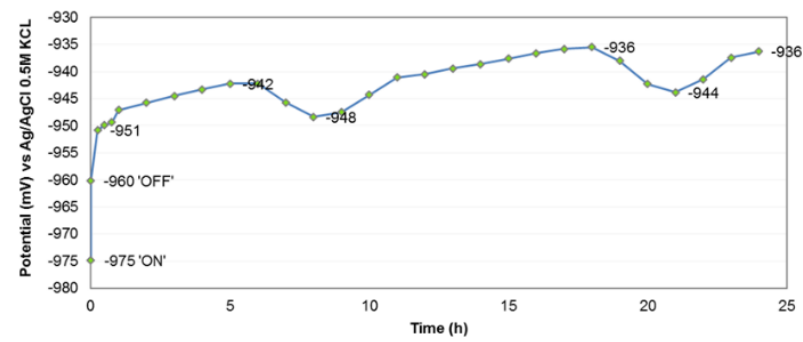

Fig. 12. Typical depolarisation behaviour of a tidal zone over a period of 24 hours.

It is for this reason that for tidal zones the performance verification was focused on corrosion risk assessment by means of corrosion current density calculation utilising the Butler-Volmer equation [5].

Although instantaneous, corrosion current densities are a useful indicator about the general risk of corrosion. When undertaken at a frequent basis, it is possible to build up a histogram of corrosion current densities which can in turn provide useful information on overall trends

Generally, rates less than $2 \mathrm{~mA} / \mathrm{m}^{2}$ are associated with benign environments that do not present a corrosion risk $[5,9,11-14,16,17]$. In all occasions, the corrosion current densities measured were less than the above threshold. When coupled with an upward trend of open steel potentials towards more positive values (as show in Figures 12 and 13 respectively) then the steel may be classified as being in a benign and non-corroding environment with very low to negligible corrosion risk.

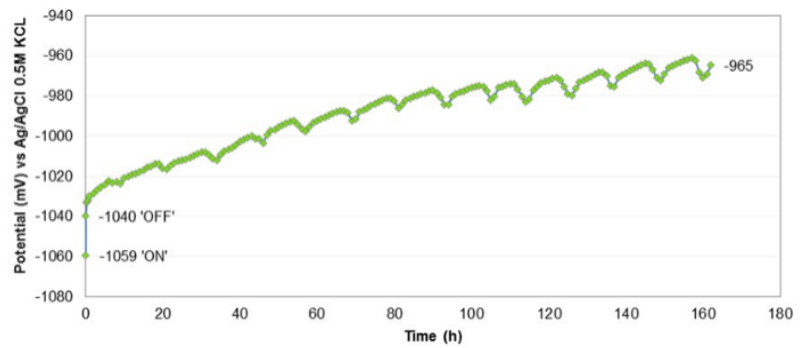

Fig. 13. Typical depolarisation behaviour of a tidal zone over a period of 160 hours.

\section{Conclusions}

Overall, this project has demonstrated that hybrid corrosion treatment is an attractive alternative to the corrosion protection of reinforced concrete elements, especially ones with difficult access. In particular, it can be concluded that:

- Hybrid corrosion treatment can be successfully applied to pre-stressed concrete and it is a viable alternative to traditional electrochemical treatments.

- It enables expedited installation in areas of constrained access such as marine structures subject to the cyclic variation of tides.

- It offers a substantially reduced residual risk against hydrogen embrittlement for the protection of prestressed concrete elements.

- Following the application of a brief current electrochemical treatment, corrosion rates have dropped below a threshold value of $2 \mathrm{~mA} / \mathrm{m}^{2}$ and have remained as such since. Furthermore, open steel potentials indicate positive trends towards more positive values. All of these, together with the depolarisation results suggest a successful treatment with the steel being at a passive and benign environment.

\section{References}

1. ASTM C1556 - 04

2. C. Andrade, C. Alonso, Test methods for on-site corrosion rate measurement of steel reinforcement in concrete by means of the polarization resistance method. RILEM TC-154-EMC, 37(273), pp. 623643 (2004)

3. U. Angst, B. Elsener, C.K Larsen, O. Vennesland, Critical chloride content in reinforced concrete - A review. Cement and Concrete Research, 39, 11221138 (2009)

4. P. Bamford, W. Price, An International Review of Chloride Ingress into Structural Concrete, TRL 
Contractor Report 359, s.1.: UK Transport Research Laboratory (1996)

5. Bristish Standard Institution, 2012. BS EN ISO 12696:2016, Cathodic protection of steel in concrete, London: BSI.

6. J. Broomfield, Corrosion of Steel in Concrete: Understanding, Investigation and Repair, 2nd edn. Taylor \& Francis, Abingdon, UK (2007)

7. C. Christodoulou, G.K. Glass, J. Webb, Corrosion management of concrete structures [technical note]. Structural Engineer, 87 (23-24), pp. 20 - 22

8. C. Christodoulou, C.I. Goodier, S.A. Austin , J. Webb, G.K. Glass, A new arrangement of galvanic anodes for the repair of reinforced concrete structures, Construction and Building Materials, 50, pp. $300-307$ (2014) DOI information: 10.1016/j.conbuildmat.2013.09.062

9. C. Christodoulou, et al., On-site transient analysis for the corrosion assessment of reinforced concrete. Corrosion Science, Volume 62, pp. 176-183 (2012)

10. C. Christodoulou, R. Kilgour, The world's first hybrid corrosion protection systems for prestressed concrete bridges. Proceedings of Corrosion \& Prevention 2013, Australasian Corrosion Association, Brisbane, Australia, paper 076 (2013)

11. C. Christodoulou, P. Corbett, N. Coxhill, Service life extension of State Highway 16 bridges - New Zealand's first hybrid corrosion protection application, Corrosion and Prevention 2016, Australasian Corrosion Association Annual Meeting, 13-16 November 2016, Auckland, New Zealand, 2016, paper 065

12. C. Christodoulou, A. Sharifi, S. Das, C.I. Goodier, Cathodic Protection on the UK's Midland Links motorway viaducts, Proceedings of the Institution of Civil Engineers: Bridge Engineering, (2013), DOI information: 10.1680/bren.12.00015

13. C. Christodoulou, et al., Assessing the long term benefits of impressed current cathodic protection. Corrosion Science, 52(8), pp. 2671-2679 (2010)

14. C. Christodoulou, et al., On-site transient analysis for the corrosion assessment of reinforced concrete. Corrosion Science, 62, pp. 176-183 (2012)

15. P.W. Corbett, T.J. Watterson, Widening of existing bridges on State Highway 16 in Auckland. Proceedings of the Institution of Civil Engineers Bridge Engineering, 169(BE3) (2016)

16. Concrete Society, Technical Report 60, Electrochemical tests for reinforcement corrosion, Surrey, UK (2004)

17. Concrete Society, Technical Report 73, Cathodic protection of steel in concrete, Surry, UK: s.n. (2011)

18. W. Dodds, C. Christodoulou, C.I. Goodier, Hybrid anode concrete corrosion protection - independent study, Proceedings of the Institution of Civil Engineers: Construction Materials, http://dx.doi.org/10.1680/jcoma.16.00024.

19. M. Dugarte, A.A. Sagüés, Galvanic point anodes for extending the service life of patched areas upon reinforced concrete bridge members. Contract No. BD544- 09. Final report to Florida Department of Transportation, Tampa, Florida; USA: September (2009)

20. G.K. Glass, C. Christodoulou, Towards rendering steel reinforced concrete immune to corrosion. Melbourne, Australia, Australasian Corrosion Association (2012)

21. G.K. Glass, B. Reddy, L.A. Clark, Making reinforced concrete immune from chloride corrosion. Proceedings of the Institution of Civil Engineers, 160, pp. 155-164 (2007)

22. G.K. Glass, A.C. Roberts, N. Davison, Hybrid corrosion protection of chloride contaminated concrete. Proceedings of the Institution of Civil Engineers, 161, pp. 163-172 (2008)

23. G.K. Glass, J.R. Chadwick, An Investigation into the Mechanisms of Protection Afforded by a Cathodic Current and the Implications for Advances in the Field of Cathodic Protection. Corrosion Science, 36, 2193-2209 (1994)

24. G.K. Glass, C. Christodoulou, S.P. Holmes, Protection of steel in concrete using galvanic and hybrid electrochemical treatments. In Concrete Repair, Rehabilitation and Retrofitting III: Proceedings of 3rd International Conference on Concrete Repair, Rehabilitation and Retrofitting, ICCRRR-3, Cape Town, South Africa (Alexander MG, Beushausen HD, Dehn F and Moyo P (eds)). pp. 523-526. CRC Press, Taylor and Francis Group (2012)

25. S.P. Holmes, G.D. Wilcox, P.J. Robins, G.K. Glass, A.C. Roberts, Long term assessment of a hybrid electrochemical treatment. Materials and Corrosion 62(9999): 43-49 (2011)

26. S.P. Holmes, C. Christodoulou, G.K. Glass, Monitoring the passivity of steel subject to galvanic protection. Proceedings of Corrosion \& Prevention 2013, Australasian Corrosion Association, Brisbane, Australia, paper 133 (2013)

27. NZTA Report 337 - Deterioration of Prestressed Concrete Bridge Beams.

28. R. Polder, A. Tondi, R. Cigna, Concrete Resistivity and Corrosion Rate of Reinforcement, TNO Report 93-r0170, s.1.: TNO Delft (1993)

29. R. Polder, W.H.A. Peelen, B.T.J. Stoop, E.A.C. Neeft Early Stage Beneficial Effects of Cathodic Protection in Concrete Structures. Eurocorr, Nice, France (2009) 